J. Clin. Chem. Clin. Biochem.

Vol. 20, 1982, pp. 633-638

\title{
The Catalytic Activity and Activation Energy of Creatine Kinase Isoenzymes
}

\author{
By U. Hagelauer and U. Faust
}

\section{Institut für Biomedizinische Technik der Universität Stuttgart}

(Received December 28, 1981/March 30, 1982)

Summary: The catalytic activity and activation energy of an enzyme are obtained by measuring the rate of the enzymic reaction at two different temperatures. With the aid of the Arrhenius equation, these two parameters can be used to calculate a value proportional to the quantity of enzyme. Using this approach to investigate the isoenzymes of creatine kinase, it was shown that the activation energy increased in the order creatine kinase MM, MB, BB. Mixtures of the isoenzymes showed an apparent mean activation energy, which likewise could be determined using the Arrhenius equation.

Ageing of the isoenzymes results in an exponential decrease of catalytic activity, accompanied by a continuous increase in activation energy, the calculated quantity of enzyme remaining constant. Inactivation is therefore not an all-or-nothing process; rather a stepwise inactivation of individual molecules must be assumed. The results of these ageing experiments and observations by other authors suggest that a similar inactivation occurs in vivo.

\section{Die katalytische Aktivität und Aktivierungsenergie der Kreatinkinase-Isoenzyme}

Zusammenfassung: Durch die Messung der Geschwindigkeit einer enzymatischen Reaktion bei zwei verschiedenen Temperaturen erhält man die katalytische Aktivität und die Aktivierungsenergie des Enzyms. Aus beiden läßt sich gemäß der Arrhenius-Gleichung eine der Enzymmenge proportionale Größe berechnen. Mit dieser Methode untersuchten wir die İsoenzyme der Kreatinkinase und stellten fest, daß die Aktivierungsenergie in der Reihenfolge Kreatinkinase MM, MB und BB ansteigt. Mischungen der Isoenzyme zeigen eine scheinbare, mittlere Aktivierungsenergie, die sich ebenfalls mit der Arrhenius-Gleichung bestimmen läßt.

Bei der Alterung der Isoenzyme in vitro fält die katalytische Aktivität exponentiell ab. Daran gekoppelt ist eine kontinuierliche Zunahme der Aktivierungsenergie, die errechnete Enzymmenge bleibt dabei konstant. Die Inaktivierung verläuft demnach nicht nach dem Alles-oder-Nichts Prinzip, vielmehr muß eine stufenweise Inaktivierung der einzelnen Moleküle angenommèn werdèn. Die Ergebnisse dieser Alterungsversuche, sowie Beobachtungen anderer Autoren lassen vermuten, daß auch in vivo eine vergleichbare Inaktivierung stattfindet.

\section{Introduction}

Proportionality between quantity of enzyme and catalytic activity is an important prerequisite for the determination of catalytic activity as an aid to clinical diagnosis. The proportionality factor depends on $\mathrm{pH}$, activators, temperature, ionic concentration, etc., and these parameters must therefore be standardized.

The proportionality factor further depends on the chemical and three dimensional structure of the enzyme. Alterations in these structures may manifest themselves as inactivation or irreversible denaturation. Proportionality is also absent if the reaction is catalysed simultaneously by several isoenzymes, which differ in their specific catalytic activities.
Of the clinically relevant enzymes, creatine kinase (EC 2.7.3.2) may have both of these limitations. In standardizing the assay temperature of creatine kinase at $25^{\circ} \mathrm{C}$, Bergmeyer (1) indicated that the enzyme is especially thermolabile and is subject to inactivation in the range $15-40^{\circ} \mathrm{C}$. Szász (2) found a decrease in catalytic activity above $30^{\circ} \mathrm{C}$, which he attributed moreover to changes in protein structure. Thermolability of the isoenzymes increases in the order creatine kinase $\mathrm{MM}, \mathrm{MB}, \mathrm{BB}^{\mathrm{l}}$ ), and, as reported by Bohner et al. (3),

\footnotetext{
1) Nonstandard abbreviations: CK: creatine kinase (ATP: creatine-phosphotransferase, EC 2.7.3.2). Creatine kinase $\mathrm{MM}, \mathrm{MB}$ and $\mathrm{BB}$ : creatine kinase isoenzymes from striated muscle, heart and brain, respectively.
} 
can be expressed in the form of different time constants of inactivation.

Accordingly, when a mixture of all isoenzymes is aged there is a shift in the proportion of catalytic activity towards that of creatine kinase MM.

Neumeier (4) compared the creatine kinase B-protein concentration determined radioimmunologically, and the creatine kinase MB catalytic activity determined by immunoinhibition, following myocardial infarction. During the elimination, the protein concentration of creatine kinase $B$ was elevated for a longer period than the creatine kinase MB catalytic activity.

The question of constant specific catalytic activity is also relevant to the calculation of the extent of infarction from the time course of creatine kinase catalytic activity $(5,6)$. In this model the ratio of catalytic activity to protein concentration is especially important, because the extent of infarction must be expressed quantitatively. Some authors have reported good agreement between the calculated value for the size of infarction and that determined angiographically, but others were unable to confirm this on large collectives of patients (7).

These observations once again raise the question of whether the isoenzymes of creatine kinase show a constant specific catalytic activity, a problem that can be resolved by the simultaneous measurement of the activation energy.

\section{Materials and Methods}

\section{Definition of activation energy}

The conventional model of an enzyme reaction, in which the dissociation of the enzyme-substrate complex is the rate limiting step, is taken as the basis for the following definition. Furthermore, it is assumed that there is substrate saturation and that the reaction in pseudo-zero order. The rate at which the substrate concentration [S] changes is then maximal and proportional to the enzyme concentration [E].

$$
\nu=\frac{\mathrm{d}[\mathrm{S}]}{\mathrm{d} t}=k \cdot[\mathrm{E}]
$$

The effect of temperature on the rate constant $k$ follows from the Arrhenius equation.

$$
\begin{aligned}
& k=\mathrm{F} \cdot \mathrm{e}^{\frac{-E^{\# \cdot T}}{R \cdot T}} \\
& \mathrm{~F}=\text { frequency factor, } E^{\#}=\text { activation energy } \\
& R=\text { gas constant }, \quad T=\text { absolute temperature }
\end{aligned}
$$

This equation can be derived and interpreted thermodynamically from the Boltzmann equation for the distribution of molecules between different energy states. The frequency factor expresses the absolute frequency of collision. For practical calculations, the frequency factor is expanded by a steric factor; it then represents the number of collisions per unit time that actually lead to reaction (8). In terms of Eyring's theory, the activation energy is the "energy barrier" which must be overcome to permit a reaction to occur. Accordingly, a high activation energy is synonymous with a low specific catalytic activity.
Formally, equations 1 and 2 can be combined:

$$
\frac{\mathrm{d}[\mathrm{S}]}{\mathrm{d} t}=[\mathrm{E}] \cdot \mathrm{F} \cdot \mathrm{e}^{\frac{-E^{\#}}{R \cdot \dot{T}}}
$$

The frequericy factor is regarded to be independent of $T$. The Arrhenius plot is a graphical representation of this equation, in which $\ln v$ is plotted against $1 / T$, and the slope of the resulting straight line is proportional to the activation energy.

For the determination of the activation energy, the reaction rates must be measured at at least two different temperatures:

$$
\nu_{1}=[\mathrm{E}] \cdot \mathrm{F} \cdot \mathrm{e}^{\frac{-E^{\#}}{R \cdot T_{1}}} \quad \nu_{2}=[\mathrm{E}] \cdot \mathrm{F} \cdot \mathrm{e}^{\frac{-E^{\#}}{R \cdot \tilde{T}_{2}}}
$$

Division and rearrangement give the activation energy and the value, $F \cdot[E]$, which is proportional to the enzyme concentration.

$$
\begin{aligned}
& E^{\#}=\frac{R \cdot T_{1} \cdot T_{2}}{T_{2}-T_{1}} \ln \frac{\nu_{2}}{\nu_{1}} \\
& \mathrm{~F} \cdot[\mathrm{E}]=\nu_{1} \cdot \mathrm{e}^{\frac{E^{\#}}{R \cdot T_{1}}}
\end{aligned}
$$

Apparent mean activation energy of isoenzyme mixtures

If the enzyme molecules do not all have the same activation energy the term, activation energy, has a different meaning. This may be the case in a mixture of isoenzymes, or it may result from alterations of chemical or three dimensional structures. An apparent mean activation energy is then observed, which can be defined as follows for general cases:

$$
E_{\mathrm{s}}^{\#}=\frac{R \cdot T_{1} \cdot T_{2}}{T_{2}-T_{1}} \ln \frac{\sum_{i=1}^{n} F_{i} \cdot\left[E_{i}\right] \cdot \mathrm{e}^{\frac{-E_{i}^{\#}}{R \cdot T_{2}}}}{\sum_{i=1}^{n} F_{i} \cdot\left[E_{i}\right] \cdot \mathrm{e} \frac{-E_{i}^{\#}}{R \cdot T_{1}}}
$$

This relationship was tested experimentally, using different mixtures of creatine kinase MM and BB. For a mixture of two isoenzymes, equation 5 can be written:

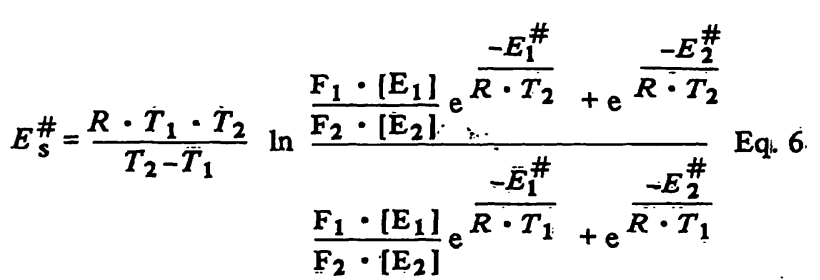

The activation energies $E_{1}^{\#}$, and $E_{2}^{\#}$, and the terms $\mathrm{F}_{1} \cdot\left[\mathrm{E}_{1}\right]$ and $F_{2} \cdot\left[E_{2}\right]$ were determined for samples of pure creatine kinase $M M$ and $B B$. The ratio $\left(\mathrm{F}_{1}\left[\mathrm{E}_{1}\right]\right) /\left(\mathrm{F}_{2} \cdot\left[\mathrm{E}_{2}\right]\right)$, and the value of $E_{s}^{\#}$ can therefore be calculated for any mixture.

\section{Analy sis system}

It follows from equation 4 that, for the determination of activation energy, the enzyme catalytic activity must be measured at two different temperatures. According to equation 4, only the ratio of the two catalytic activities is needed, not their absolute values. The determination should be performed in one reaction mixture, avoiding the pipetting errors inherent in separate incubations.

For example, if catalytic activity is determined at $25^{\circ} \mathrm{C}$ and $35^{\circ} \mathrm{C}$, and an accuracy of $\pm 1 \mathrm{~kJ} / \mathrm{mol}$ is required in the determination of the activation energy, these two temperatures must be controlled to within $\pm 0.05 \mathrm{~K}$ during the linear progress of the reaction (10). This is not possible with conventional systems. We developed a method for achieving the required accuracy of temperature control by using the heating effect of ultrasound coupled into the cuvet.

This results in rapid and homogeneous heating $(d T / \mathrm{d} t=0.5 \mathrm{~K} / \mathrm{s}$ ) and a temperature accuracy of $\pm 0.03 \mathrm{~K}(9)$. At the ultrasonic energy level used $\left(2.1 \mathrm{~W} / \mathrm{cm}^{3}\right)$ we observed no inactivation or denaturation. 
Systematic or fortuitous deviations from linear, pseudo-zero order kinetics have a greater effect on the determination of activation energy than on catalytic activity measurements. The magnitude of the following influences was therefore investigated:

\section{Incubation time}

The first $3 \mathrm{~min}$ of incubation are unsuitable for analytical purposes, due to a lag phase and the reactivation of creatine kinase by $\mathrm{N}$-acetylcysteine. The lag phase lasts for 1 to $3 \mathrm{~min}$ and can occasionally be as long as $5 \mathrm{~min}$. After $5 \mathrm{~min}$ at $25^{\circ} \mathrm{C}$, reactivation is $99 \%$ (11). Incubation was therefore performed for $5 \mathrm{~min}$ at $25^{\circ} \mathrm{C}$ before the determination of activation energy.

\section{Catalytic activity}

With low substrate turnover and only small alterations in absorbance, errors arise from the limited resolution of the photometer (digitalization errors). If the catalytic activity is too high, the course of the reaction deviates from linear in the second measurement step at $35^{\circ} \mathrm{C}$, and the resulting value for the activation energy is too low. An initial measurement of the catalytic activity of the sample was therefore made, and the sample volume for the measurement of the activation energy was chosen to give a crcatine phosphate conversion between 5 and $25 \mu \mathrm{mol} / \mathrm{min} \cdot 1$.

\section{Evaluation}

Errors caused by deviations from linearity, which can be caused, for example, by impurities in the sample, were minimized by on-line recording of the photometric data, followed by their evaluation in a desk calculator (10).

The N-acetylcysteine reactivation method was used for the determination of activation energy. This corresponds to the recommended standard method of the German Society for Clinical Chemistry (reagents: Creatine Kinase Test System, Merck, Darmstadt), and is based on the reverse reaction:

\section{Creatine Phosphate + ADP $\rightarrow$ Creatine + ATP}

The term, activation energy, therefore corresponds to the transition energy for the dissociation of creatine from the creatine phosphate-creatine kinase complex.

\section{Experimental material}

Isoenzymes of creatine kinase from human heart, uterus, skeletal muscle and serum, prepared by the method of Bohner et al. (3), were obtained from the IV Department of Internal Medicine, University Clinic, Tübingen (Abteilung für Innere Medizin IV, Medizinische Universitätsklinik Tübingenn).
Twelve serum samples from infarct patients, provided by the Cardiology Department of the Katharinen Hospital Stuttgart, were used for the studies on enzyme ageing. The sera were centrifuged $5 \mathrm{~min}$ at $2200 \mathrm{~g}$ with sure-sep, then aged at $30^{\circ} \mathrm{C}$ or $37^{\circ} \mathrm{C}$ without addition of SH-protective agents. Ageing of creatine kinase MM was studied in samples that showed only a very low content of creatine kinase MB. This was determined by an immunoinhibition test (No. 300691, Boehringer Mannheim), and was lower than $0.3 \%$ in the samples used. Creatine kinase isoenzyme MB was separated from sera containing a high proportion of the isoenzyme, using DEAE Sephadex A-50 chromatography. Ageing studies on isoenzyme MB were performed with the aid of a test kit (No. 189219, Boehringer, Mannheim).

\section{Results}

\section{Activation energy of the isoenzymes}

Table 1 lists the measured activation energies of creatine kinase isoenzymes MM, MB and BB (Nos. 1-7). The activation energies of the isoenzymes are markedly different and they increase in the order MM, MB, BB. Isoenzyme MM stands apart with a significantly lower value than the other two isoenzymes. The scatter of values for the activation energy of $\mathrm{MM}$ or $\mathrm{MB}$ lies within the experimental accuracy of $\pm 1 \mathrm{~kJ} / \mathrm{mol}$, but the different values for creatine kinase $\mathrm{BB}$ cannot be explained in this way. Table 1 also contains conversion factors (Nos. 8-11) for comparison of catalytic activities at different reaction temperatures $(11,12,13,14)$. These factors can be used to calculate the activation energy according to equation 4 . Values calculated in this way and the experimentally determined values all lie in the range $49-62.8 \mathrm{~kJ} / \mathrm{mol}$.

\section{Activation energy of mixtures of isoenzymes}

Mixtures were prepared from isoenzymes No. 1 and No. 6 (tab. 1), then used to test for correspondence between the experimental and calculated (equation 6)

Tab. 1. Catalytic activity $(\mathrm{U} / \mathrm{l})$, activation energy $(\mathrm{kJ} / \mathrm{mol})$ and $\mathrm{F} \sim[\mathrm{E}](\mu \mathrm{mol} / 1 \cdot \mathrm{min})$ of creatine kinase.

Values 1 - 7: determined on isoenzyme preparations from organs and serum ( \pm 1 standard deviation).

Values 8-11: values for activation energy calculated using conversion factors from the literature.

\begin{tabular}{|c|c|c|c|c|c|c|c|}
\hline. & $\begin{array}{l}\text { Iso-: } \\
\text { enzyme }\end{array}$ & $\begin{array}{l}\text { Source or } \\
\text { literature } \\
\text { reference }\end{array}$ & $\begin{array}{l}\text { Num- } \\
\text { ber of } \\
\text { deter- } \\
\text { mina- } \\
\text { tions }\end{array}$ & $\begin{array}{l}\text { Conversion factor } \\
\left(T_{1} \text { to } T_{2}\right)\end{array}$ & $\begin{array}{l}\text { Catalytic } \\
\text { activity } \\
{[\mathrm{U} / 1]} \\
\end{array}$ & $\begin{array}{l}\text { Activation } \\
\text { energy } \\
{[\mathrm{kJ} / \mathrm{mol}]}\end{array}$ & $\begin{array}{l}F \cdot[E] \\
{[\mu \mathrm{mol} / 1 \cdot \min ]}\end{array}$ \\
\hline $\begin{array}{l}1 \\
2 \\
3 \\
4 \\
5 \\
6 \\
7\end{array}$ & $\begin{array}{l}\mathrm{MM} \\
\mathrm{MM} \\
\mathrm{MM} \\
\mathrm{MB} \\
\mathrm{MB} \\
\mathrm{BB} \\
\mathrm{BB}\end{array}$ & $\begin{array}{l}\text { Heart } \\
\text { Skeletal muscle } \\
\text { Skeletal muscle } \\
\text { Heart } \\
\text { Serum } \\
\text { Uterus } \\
\text { Serum }\end{array}$ & $\begin{array}{l}6 \\
6 \\
4 \\
5 \\
6 \\
5 \\
5\end{array}$ & & $\begin{array}{r}715 \pm 24 \\
1470 \pm 45 \\
1420 \pm 39 \\
688 \pm 19 \\
72 \pm 2 \\
1360 \pm 84 \\
76 \pm 3\end{array}$ & $\begin{array}{l}49.4 \pm 1.3 \\
49.0 \pm 1.1 \\
50.5 \pm 0.9 \\
59.0 \pm 0.9 \\
57.4 \pm 1.4 \\
62.8 \pm 2.0 \\
61.4 \pm 1.7\end{array}$ & $\begin{array}{l}3.3 \cdot 10^{11} \\
5.7 \cdot 10^{11} \\
1.0 \cdot 10^{12} \\
1.5 \cdot 10^{13} \\
8.3 \cdot 10^{11} \\
1.4 \cdot 10^{14} \\
4.4 \cdot 10^{12}\end{array}$ \\
\hline $\begin{array}{r}8 \\
9 \\
10 \\
11\end{array}$ & .. & $\begin{array}{l}(11) \\
(12) \\
(13) \\
(14)\end{array}$ & & $\begin{array}{l}1.4 \quad\left(25^{\circ} \mathrm{C} \rightarrow 30^{\circ} \mathrm{C}\right) \\
0.42 .\left(37^{\circ} \mathrm{C} \rightarrow 25^{\circ} \mathrm{C}\right) \\
2.44\left(25^{\circ} \mathrm{C} \rightarrow 37^{\circ} \mathrm{C}\right) \\
0.39\left(37^{\circ} \mathrm{C} \rightarrow 25^{\circ} \mathrm{C}\right)\end{array}$ & & $\begin{array}{l}50.52 \\
55.52 \\
57.09 \\
60.27\end{array}$ & \\
\hline
\end{tabular}


apparent mean activation energies. The initial preparations from uterus and heart muscle contained only isoenzymes $\mathrm{MM}$ or $\mathrm{BB}$, respectively.

Figure 1 shows the $E_{s}^{\#}$ of various mixtures. There is good agreement between measured values and those calculated according to equation 6 . This means that the catalytic activities of the individual isoenzymes are undisturbed and overlap one another, and that the Arrhenius equation remains valid for each isoenzyme.

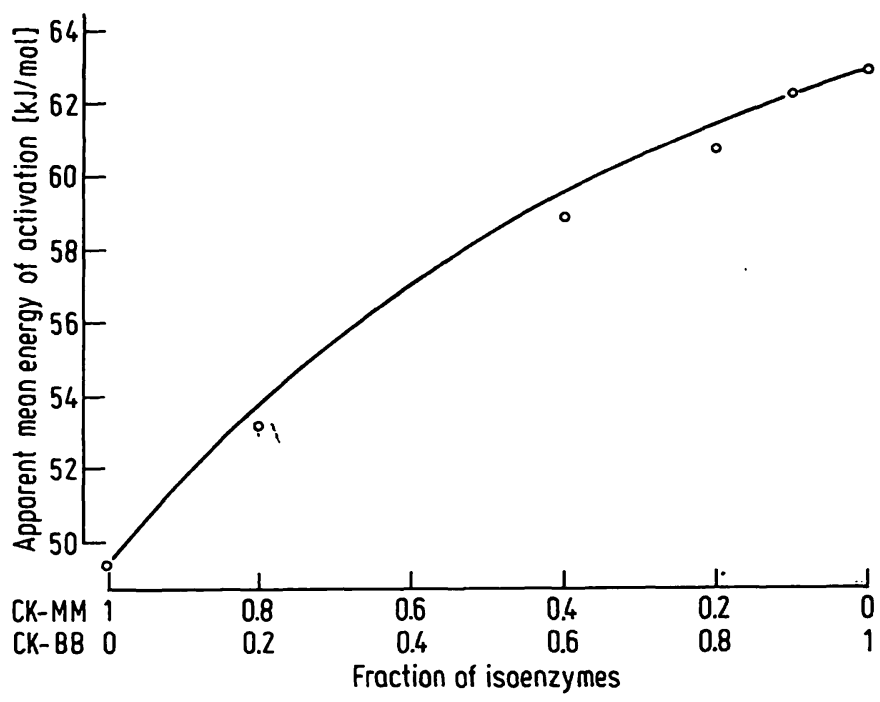

Fig. 1. Apparent mean activation energy $(\mathrm{kJ} / \mathrm{mol})$ of mixtures of creatine kinase (CK) MM and BB. For the catalytic activity and activation energy of the starting samples, see table 1, Nos. 1 and 6.

- curve calculated according to equation 6 $\circ \circ \circ$ experimentally determined values

\section{Ageing of isoenzymes $M M$ and $M B$}

Enzyme ageing was investigated in patient sera in vitro at $30^{\circ} \mathrm{C}$ or $37^{\circ} \mathrm{C}$, without addition of SH-protective agents.

Figure 2 shows the course of catalytic activity, activation energy and the quantity term, $F \cdot$. [E] for creatine kinase MM. The same type of curve was observed for creatine kinase $\mathrm{MB}$, but with more rapid inactivation. An exponential decrease of catalytic activity is accompanied by a corresponding increase in the activation energy. Catalytic activity can be expressed by an exponentially decreasing time function, $v(t)=a \cdot \exp (-b \cdot t)$, the coefficients $a$ and $b$ being determined by regression. Time constant $b$ for creatine kinase MB was measured at $30^{\circ} \mathrm{C}$, because the rate of inactivation of creatine kinase of $\mathrm{MB}$ at $37^{\circ} \mathrm{C}$ is much more rapid than that of creatine kinase $\mathrm{MM}$ and allows insufficient time for the determination of activation energy. The time constants

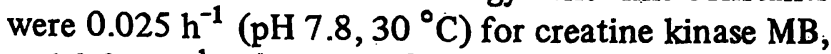
and $0.064 \mathrm{~h}^{-1}$ (pH 8.1, $37^{\circ} \mathrm{C}$ ) for creatine kinase $\mathrm{MM}$. The numerical values of these time constants can only serve as a guide, since the possible influence of the serum composition and the chromatographic separation step for creatine kinase $\mathrm{MB}$, etc. were not investigated. Nevertheless, the values for the in vitro inactivation largely coincide with the results of other authors (3) and with values observed after myocardial infarction (7).
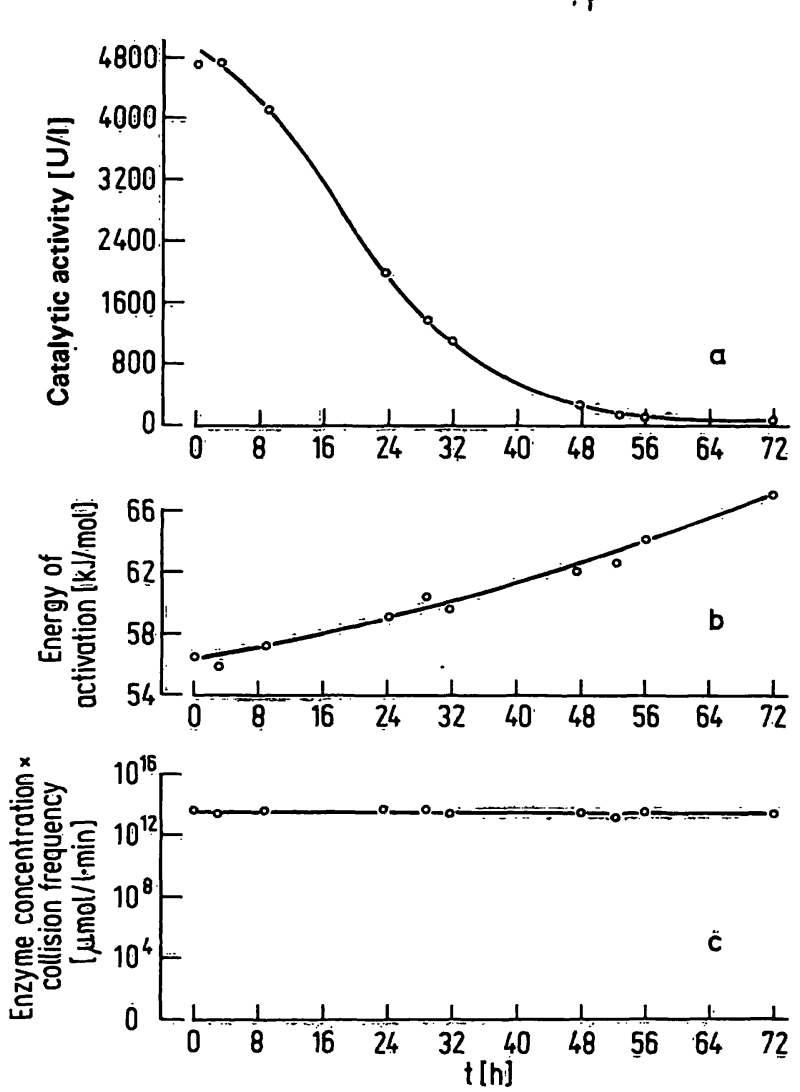

Fig. 2. Catalytic activity (a), apparent mean activation energy (b) and $F \cdot[E]$ (c) during the ageing of creatine kinase $\mathrm{MM}$ in vitro at $37^{\circ} \mathrm{C}(\mathrm{pH} 8.1)$, measured in patient serum without addition of SH-protective agents.

In all ageing experiments, the quantity term, $F \cdot[\mathbb{E}]$, remained approximately constant. The two-fold variation observed in the value of this term can be explained by the experimental error of $\pm 1 \mathrm{~kJ} / \mathrm{mol}$ ( 1 standard deviation) in the measurement of the activation energy.

\section{Discussion}

The following observations were made:

1) The activation energy of the creatine kinase isoenzymes increases in the order $\mathrm{MM}, \mathrm{MB}, \mathrm{BB}$.

2) Mixtures of isoenzymes of differing activation energies yield an apparent mean activation energy. This value can be determined (with the aid of the Arrhenius equation) by measurement of the catalytic activity at two temperatures, or it can be calculated from the ratio of the isoenzymes present in the mixture (see equation 6). The two values are in good agreement, which means that the Arrhenius equation is also valid for isoenzyme mixtures. 
3) Ageing of isoenzymes in vitro results in a decrease of catalytic activity, coupled with an increase in activation energy. At the same time the product of frequency factor $x$ enzyme concentration (calculated according to the Arrhenius equation) remains constant. Creatine kinase MB is more thermolabile than creatine kinase MM.

The following conclusions can be drawn from these observations:

a) Differences in activation energy are responsible for differences in the effect of temperature on cataly tic activity. The measured catalytic activity of isoenzyme mixtures of unknown composition cannot be reliable recalculated for different temperatures, except in the case of a very small temperature interval. If the variation range of the activation energy in known, this interval can be calculated for a given margin of error (15).

b) The activation energy for the dissociation of creatine from the enzyme-substrate complex increases in the order $\mathrm{MM}, \mathrm{MB}, \mathrm{BB}$. In order to catalyse a certain substrate turnover, creatine kinase BB must therefore be present in greater concentration and/or have a higher molecular collision factor than the other two isoenzymes.

Since the catalytic activity of creatine kināse $M B$ is halved by immunoinhibition of the M-subunit, it would seem that different frequency factors are involved. These can only be determined, however, by a comparative study using an additional method for the measurement of the enzyme concentration (e.g. RIA).

Comparison of the results for creatine kinase MM (sample No. 2) and creatine kinase BB (sample No. 6) shows that the term $F \cdot[E]$ differs by almost three orders of magnitude, despite comparable catalytic activities. This can be explained by the nature of the exponential function and the numerical value $R \cdot T=2.47 \mathrm{~kJ} / \mathrm{mol}$ (at $25^{\circ} \mathrm{C}$ ). Thus a change of äctivation energy has a much more pronounced effect on the specific catalytic activity of an enzyme than does a change in the frequency factor.

This is also apparent from the ageing experiments. In the case of creatine kinase MM, the catalytic activity decreased by a factor of 100 , but the activation energy increased only 1.2-fold. The increase of reaction rate from $25^{\circ} \mathrm{C}$ to $35^{\circ} \mathrm{C}$ showed $\mathrm{Q}=2.1$ bèfore ageing, and 2.4 after ageing. Recalculation of catalytic activity of an enzyme for different temperatures is therefore also subject to errors due to enzyme ageing.

The nearly constant value for the term $F \cdot[E]$ during the ageing shows that the inactivation. of the enzyme can be explained entirely by the decrease in its specific catalytic activity. Inactivation apparently does not proceed according to an all-or-nothing principle. If this were the case, normal, active molecules would be present alongside fully inactive molecules. Since inactive mole- cules make no contribution to substrate turnover, and consequently cannot contribute to the temperaturedependent rate increase, the activation energy would then be constant. The same result is obtained if equation 6 is considered for very large values of $E_{1}^{\#}$ or $E_{2}^{\#}$.

It is possible to attribute this continual rise in activation energy to the appearance of more or less inactive intermediate forms with different activation energies, as already reported for other enzymes, e.g. fumarase (16). The aged enzyme can be considered as a mixture of enzymes of different activation energies, which shows the same properties as mixtures of isoenzymes (see fig. 1). To explain the mechanism of ageing with certainty, however, further investigations are needed, especially into the accompanying chemical and structural alterations (17).

The question arises as to whether a similar mechanism of inactivation could occur in vivo. This possibility is supported by two observations mentioned at the outset:

1) After a myocardial infarction, the protein concentration of creatine kinase $B$ remains elevated for a longer period than the catalytic activity of MB.

2) The inactivation time constant measured in vitro shows good agreement with the values obtained for the elimination of the enzyme after myocardial infarction; this observations indicate that the decrease of catalytic activity is not due entirely to elimination (clearance) of the enzyme, but also to its inactivation in vivo.

These observations have important implications for the calculation of infarct size. Indeed it is irrelevant whether the time constant for the decrease actually describes the elimination or inactivation of the enzyme. It is crucial, however, that the creatine kinase MM and MB decrease with different time constants and have different activation energies, so that there is no firm relationship between enzyme catalytic activity and its protein concentration. A strict relationship between these two parameters is, however, the very assumption upon which the recommended methods for calculation of infarct size are based. It is therefore important to investigate whether a similar inactivation occurs in vivo.

\section{Acknowledgements}

We thank Dr. J. Bohner and Dr. Dr. W. Stein, Medizinische Universitätsklinik Tübingen Abteilung Innere Medizin IV (Director Prof. Dr. M. Eggstein), for suggesting the study of enzyme ageing by measurement of activation energies, and for providing the isoenzyme preparations. Dr. Ehret, Abt. Herz- und Gefaßßkrankheiten (Medical director Prof. Dr. A. Both) and Dr. Chr. Trendelenburg, Klinisch-Chemisches Institut (Medical director Prof. Dr.J. D. Kruse-Jarres) at the Katharinen Hospital Stuttgart gave valuable assistance in the taking and processing of samples. For precious advices and discussion we gratefully acknowledge Prof. Dr. Dr. H. Keller, Kantonsspital St. Gallen, Switzerland. 


\section{References}

1. Bergmeyer, H. U. (1973) J. Clin. Chem. Clin. Biochem. 11, 39-45.

2. Szasz, G. (1974) J. Clin. Chem. Clin. Biochem. 12, 166170.

3. Bohner, J., Stein, W., Renn, W., Steinhart, R. \& Eggstein, M. (1981) J. Clin. Chem. Clin. Biochem. 19, 1021-1026.

4. Neumeier, D. (1981) Measurement of Creatine Kinase Isoenzyme Concentration by Immunoassay. In: Creatine Kinase Isoenzymes, (Lang, H., ed.), Berlin, Springer, pp. 7583.

5. Merx, W. (1979) Verh. Dtsch. Ges. Herz- u. Kreislaufforschg. 45, 61-75.

6. Sobel, B. E., Roberts, R. \& Larson, K. B. (1976) Amer. J. Cardiol. 37, 474-485.

7. Habel, F. (1980) Z. Kardiol. 69, 11-17.

8. Netter, H. (1959) Theoretische Biochemie. Berlin, Springer, pp. 564-566.
9. Hagelauer, U., Arnạudov, K. \& Faust, U. (1980) Biomed. Technik 25, 242-246.

10. Hagelauer, U. \& Faust, U. (1981) Biomed. Technik 26, 135-136.

11. Helger, R. (1981) Methods for Differentiation and Quantitation of Creatine Kinase İsoenzymes. In 'Creatine Kinase Isoènzymes, (Lang, H., ed.), Bertlin, Springer, pp. $31-83$.

12. Szasz, E., Busch, E. W. \& Farohs, H. B. (1970) Dtsch. Med. Wochenschr. 95, 829-835.

13. Modulab Guide File: Fidelity in Diagnostic Photometrie. Firmenschrift: Boehringer, Mannheim, E 12775.

14. Rosalki, S. B. (1967) J. Lab. Clin. Med. 69, 696.

15. Hagelauer, U. \& Faust, U. (1980) Biomed. Technik 25, 6267.

16. Dixon, M. \& Webb, C. (1979) Enzymes. 3rd ed., New York, Acad. Press, pp. 170-180.

17. Morin, L. G. (1977) Clin. Chem. 23, 646-652.
Prof. Dr.-Ing. U. Faust Dipl. Ing. U. Hagelauer Institut für Biomedizinische Technik der Universität Stuttgart

Azenbergstr. 18

D-7000 Stuttgart-1 